\title{
Impact of Nutrient Levels and Growth Regulators on Yield, Plant Nutrient Content, Plant Nutrient Uptake and Soil Nutrient Content of transplanted Pigeonpea in Northern Transition Zone of Karnataka
}

\author{
C. Lavanya ${ }^{1 *}$, H.B. Babalad ${ }^{2}$ and P.L. Patil ${ }^{3}$ \\ ${ }^{1}$ Department of Agronomy, ${ }^{3}$ Department of Soil Science and Agricultural Chemistry, \\ College of Agriculture, UAS, Dharwad-580005, Karnataka India \\ ${ }^{2}$ Department of Agronomy, College of Agriculture, Vijayapura, UAS, Dharwad-580005, \\ Karnataka, India \\ *Corresponding author
}

\section{A B S T R A C T}

\section{Keywords}

Growth regulators, Nutrients, Content, Uptake and

Transplanted Pigeonpea

Article Info

Accepted:

10 July 2020

Available Online:

10 August 2020
A field experiment was conducted at Main Agricultural Research Station, UAS, Dharwad during kharif, 2017 to study the effect of nutrient levels and growth regulators on yield, plant nutrient content, plant nutrient uptake and soil nutrient content of transplanted pigeonpea under rainfed conditions. The experiment comprising of 3 nutrient levels as main plots and 4 sub plot treatments of foliar application of micronutrients and growth regulators compared with 1 single control were laid out in split plot design with 3 replications. The results showed that among nutrient levels, application of 50:100 N:P $\mathrm{O}_{5} \mathrm{~kg} \mathrm{ha}^{-1}\left(\mathrm{~N}_{3}\right)$ recorded significantly higher organic carbon, nitrogen, phosphorus and potassium content in soil after harvest and significantly higher nitrogen, phosphorus and potassium uptake by crop at harvest. Significantly higher zinc uptake was recorded with application of 25:50 N:P $\mathrm{P}_{5} \mathrm{~kg} \mathrm{ha}^{-1}\left(\mathrm{~N}_{1}\right)$. Significantly higher grain yield was recorded with 37.5:75 N:P $\mathrm{P}_{5} \mathrm{~kg} \mathrm{ha}^{-1}\left(\mathrm{~N}_{2}\right)$ as compared to $\mathrm{N}_{1}$ which was at par with $\mathrm{N}_{3}$. Among the interactions, significantly higher nitrogen uptake and grain yield was recorded with application of $\mathrm{N}_{2}$ along with foliar spray of salicylic acid $(0.02 \%)+\mathrm{ZnSO}_{4}(0.5 \%)+$ soluble boron $(0.2 \%)\left(\mathrm{F}_{2}\right)$. Significantly higher phosphorus and potassium uptake was recorded with treatment $\mathrm{N}_{3} \mathrm{~F}_{2}$.

\section{Introduction}

Pulses are the important group of food crops belonging to the family Fabaceae. India ranks first in both area and production of all important pulses grown during kharif. As the pulses are mostly grown in rainfed conditions, special care and management has to be taken to sustain productivity. Low yield of pulses is also due to the fact that they are sown on 
marginal lands with low fertility and poor nutrition, because of this we are unable to harness 50 per cent of their potential yield levels. To meet the present requirements and fulfill the future projected demands of pulses by 2030 A.D., an annual growth rate of 4.2 per cent production is required. Hence, there is a need to enhance the productivity of pulses by optimizing the plant nutrition by providing macro and micro nutrients and growth regulators.

Pigeonpea [Cajanus cajan (L.) Millsp.] is one of the most important remunerative pulse crops which is being cultivated and consumed by major countries of the world. It also plays an important role in sustaining soil fertility by adding large quantity of leaf litter improving, deep root system and fixing atmospheric nitrogen. Pigeonpea, being a legume is capable of fixing atmospheric nitrogen through symbiosis but the symbiotic nitrogen fixation alone is not enough to meet high nitrogen requirements of the crop. Unlike direct sown pigeonpea transplanted crop puts up more growth, accumulate more dry matter, bear more pods and produce higher yield, and hence the nutrient demand by the crop is more. In order to ensure the optimum nitrogen requirement and to meet the potential demand of the crop, application of nitrogenous fertilizers needs to be assessed. Further, pigeonpea response to phosphorus have been generally positive and in some cases highly significant realized that it improves growth and yield attributes, root and nodule development. Therefore, phosphorus is a key nutrient for increasing productivity of pulses in general and pigeonpea in particular.

Supplemental nutrition of micro-nutrients plays a crucial role in increasing seed yield in pulses (Chandrashekar and Bangarusamy, 2003). Foliar application of micro nutrients is considered to be an efficient and economic method to supplement the requirement of the crop which in turn leads to enhanced yield. In addition, it was found more advantageous than soil application with the elimination of losses through leaching and precipitation thereby increases its use efficiency. Boron is highly water soluble, hence lost by leaching when applied to the soil. To avoid this, boric acid or solubor (a soluble commercial borate) are used for foliar application thus meeting the boron requirement of the crop efficiently. Application of growth regulators helps in better growth and also help in retention of more number of pods per plant which ultimately leads to increased biological yield thereby, increase the nutrient uptake per plant.

The low yield of pigeonpea is mainly attributed to inadequate and imbalanced nutrient application particularly with respect to nitrogen and phosphorus. Several studies showed that the transplanted pigeonpea has higher yield potential compared to direct sown pigeonpea (Jamadar et al., 2014, Sujatha and Babalad, 2018). The potential yield could be achieved in transplanted pigeonpea with optimizing the nutrient requirement of crops and use of growth regulators for better retention of flowers and pods. This necessitates the evaluation of nutrient levels for transplanted pigeonpea along with growth regulators as the present recommendations are for the direct sown pigeonpea. With this background, the present investigation was conducted to find out the optimum nutrient requirement for higher yield of transplanted pigeonpea.

\section{Materials and Methods}

The experiment was conducted at Main Agricultural Research Station, University of Agricultural Sciences, Dharwad, Karnataka on medium deep black soils under rainfed condition during kharif 2017. During the crop growth period, a total rainfall of $582.8 \mathrm{~mm}$ was received which was optimum for good 
growth and higher yield. The soil of the experimental site was clay with $\mathrm{pH}$ of 7.1 and EC of $0.32 \mathrm{dS} \mathrm{m}^{-1}$. The soil was medium in organic carbon $(0.53 \%)$ and low in available nitrogen $\left(249 \mathrm{~kg} \mathrm{ha}^{-1}\right)$ and medium in available $\mathrm{P}_{2} \mathrm{O}_{5}\left(28 \mathrm{~kg} \mathrm{ha}^{-1}\right)$ and available $\mathrm{K}_{2} \mathrm{O}$ $\left(286 \mathrm{~kg} \mathrm{ha}^{-1}\right)$. The experiment comprising of three nutrient levels $\left(25: 50 \mathrm{~N}: \mathrm{P}_{2} \mathrm{O}_{5} \mathrm{~kg} \mathrm{ha}^{-1}\right.$, 37.5:75 N: $\mathrm{P}_{2} \mathrm{O}_{5} \mathrm{~kg} \mathrm{ha} \mathrm{ha}^{-1}$ and 50:100 N:P $\mathrm{O}_{5} \mathrm{~kg}$ $\mathrm{ha}^{-1}$ ) as main plot treatments and four subplots mainly, foliar application of micronutrients and growth regulators [NAA $(0.05 \%)+$ zinc sulphate $(0.5 \%)+$ soluble boron $(0.2 \%)$, salicylic acid $(0.02 \%)+$ zinc sulphate $(0.5 \%)$ + soluble boron $(0.2 \%)$, zinc sulphate $(0.5 \%)$ + soluble boron $(0.2 \%)$ and Control (No growth regulators and micronutrients)] as sub plot treatments and one single control (FYM 6 $\mathrm{t} \mathrm{ha}^{-1}+25: 50 \mathrm{~N}: \mathrm{P}_{2} \mathrm{O}_{5} \mathrm{~kg} \mathrm{ha}^{-1}+\mathrm{ZnSO}_{4} 15 \mathrm{~kg}$ $\mathrm{ha}^{-1}+$ soluble boron $2.5 \mathrm{~kg} \mathrm{ha}^{-1}$ soil application at the time of planting) was laid out in split plot design with three replications.

Seeds of pigeonpea variety TS 3R were dry seed dressed with Trichoderma at the rate of 4 $\mathrm{g} \mathrm{kg}^{-1}$ seeds and later treated with Rhizobium and Pseudomonas fluroscence cultures at the rate of $500 \mathrm{~g} \mathrm{ha}^{-1}$ seed. The seedlings were raised in polythene bags from last week of May to last week of June for 4 weeks. With the help of marker the hills were made at 120 $\mathrm{cm} \times 60 \mathrm{~cm}$ spacing and seedlings were transplanted immediately after receipt of rain during last week of June. The recommended quantity of FYM $\left(6 \mathrm{t} \mathrm{ha}^{-1}\right)$ was applied two weeks before transplanting of the crop. Nitrogen and phosphorus were applied in the form of urea and DAP, respectively. The entire quantity of nitrogen and phosphorus fertilizers were applied as per the treatments (25:50 N: $\mathrm{P}_{2} \mathrm{O}_{5} \mathrm{~kg} \mathrm{ha}^{-1}, 37.5: 75 \mathrm{~N}: \mathrm{P}_{2} \mathrm{O}_{5} \mathrm{~kg} \mathrm{ha}^{-1}$ and 50:100 N:P $\mathrm{P}_{2} \mathrm{O}_{5} \mathrm{~kg} \mathrm{ha}^{-1}$ ) to each plot by ring method around the plant and covered with soil. Foliar application of growth regulators NAA $(0.05 \%)$ and salicylic acid $(0.02 \%)$ along with micronutrients $\mathrm{ZnSO}_{4}$
$(0.5 \%)$ and soluble boron $(0.2 \%)$ were applied at flowering and 15 days after flowering. At each foliar application, 7501 of spray solution mixture per ha was used. Spray solution was prepared accordingly with the recommended concentrations and the zinc sulphate was neutralized with lime before spray in order to avoid scorching effect on plants.

\section{Results and Discussion}

Effect of nutrient levels and growth regulators on yield of transplanted pigeonpea

The growth and yield attributing characters of transplanted pigeonpea were found to be greatly influenced by soil fertility and application of nutrients. Significantly higher grain yield (2958 kg ha ${ }^{-1}$ ) was recorded with application of $37.5: 75 \mathrm{~N}: \mathrm{P}_{2} \mathrm{O}_{5} \mathrm{~kg}$ per hectare as compared to present recommended dose of 25:50 N: $\mathrm{P}_{2} \mathrm{O}_{5} \mathrm{~kg}$ per hectare $\left(2673 \mathrm{~kg} \mathrm{ha}^{-1}\right)$ but it was statistically on par $\left(2908 \mathrm{~kg} \mathrm{ha}^{-1}\right)$ with application of $50: 100 \mathrm{~N}: \mathrm{P}_{2} \mathrm{O}_{5} \mathrm{~kg}$ per hectare (Table 1).

The increase in yield with application of 37.5:75 $\mathrm{N}: \mathrm{P}_{2} \mathrm{O}_{5} \mathrm{~kg}$ per hectare over application of $25: 50 \mathrm{~N}: \mathrm{P}_{2} \mathrm{O}_{5} \mathrm{~kg}$ per hectare was 10 per cent (Table 1). Yield is dependent upon the sum total of growth and development of crop at different phenological stages and is the cumulative expression of different yield attributes mainly number of pods per plant, number of seeds per pod and test weight of seeds. These findings are in conformity with the findings of Siddaraju (2008) who recorded higher growth and yield in cluster bean on application of fertilizer dose at 50:100:60 kg N: $\mathrm{P}_{2} \mathrm{O}_{5}: \mathrm{K}_{2} \mathrm{O}$ per hectare.

Among different foliar sprays of micronutrients and growth regulators at flowering and 15 days after flowering in 
transplanted pigeonpea, foliar spray of salicylic acid $(0.02 \%)+\mathrm{ZnSO}_{4}(0.5 \%)+$ soluble boron $(0.2 \%)$ recorded significantly higher grain yield (3230 kg ha $\left.{ }^{-1}\right)$ as compared to no spray which recorded significantly lower grain yield (2307 $\left.\mathrm{kg} \mathrm{ha}^{-1}\right)$. These findings are in accordance with those of Rajabi et al., (2013) who recorded that on foliar application of 1200 micromolar of salicylic acid increased the maximum number of pods per plant in chickpea. Foliar spray of micronutrients alone also recorded on par results with respect to grain yield (3039 $\mathrm{kg} \mathrm{ha}{ }^{-1}$ ) when salicylic acid was sprayed along with micronutrients (Table 1).

Husk and stalk yield is primarily a function of vegetative growth of the crop in terms of number of leaves per plant.. In the present study, application of balanced fertilization significantly influenced the husk and stalk yield $\left(11511 \mathrm{~kg} \mathrm{ha} \mathrm{ha}^{-1}\right)$ of transplanted pigeonpea at 50:100 N: $\mathrm{P}_{2} \mathrm{O}_{5} \mathrm{~kg}$ per hectare but it was on par with 37.5:75 N: $\mathrm{P}_{2} \mathrm{O}_{5} \mathrm{~kg}$ per hectare, respectively (Table 1). The better fertilization to the crop and other management practices influence the husk and stalk yield of the crop positively. The findings were also in accordance with Singh et al., (2006) in pigeonpea who reported that by increasing the nutrient levels upto 150 and 200 per cent RDF there was increased husk and stalk yield.

Interactions between nutrient levels and foliar spray of micronutrients and growth regulators

Significantly higher grain yield (3484 $\mathrm{kg} \mathrm{ha}^{-1}$ ) was recorded with application of 37.5:75 $\mathrm{N}: \mathrm{P}_{2} \mathrm{O}_{5} \mathrm{~kg}$ per ha along with foliar spray of salicylic acid $(0.02 \%)+\mathrm{ZnSO}_{4}(0.5 \%)+$ soluble boron $(0.2 \%)$ when compared to other treatment combinations except with the application of $37.5: 75 \mathrm{~N}: \mathrm{P}_{2} \mathrm{O}_{5} \mathrm{~kg}$ per ha along with foliar spray of salicylic acid $(0.02 \%)+$ $\mathrm{ZnSO}_{4}(0.5 \%)+$ soluble boron $(0.2 \%)$, foliar spray of NAA $(0.05 \%)+\mathrm{ZnSO}_{4}(0.5 \%)+$ soluble boron $(0.2 \%)$ and foliar spray of $\mathrm{ZnSO}_{4}(0.5 \%)+$ soluble boron $(0.2 \%)$ and application of $50: 100 \mathrm{~N}: \mathrm{P}_{2} \mathrm{O}_{5} \mathrm{~kg}$ per ha along with foliar spray of salicylic acid $(0.02 \%)+$ $\mathrm{ZnSO}_{4}(0.5 \%)+$ soluble boron $(0.2 \%)$ and foliar spray of $\mathrm{ZnSO}_{4}(0.5 \%)+$ soluble boron $(0.2 \%)$ which were on par with each other (Table 1). Similar results were recorded in pigeonpea by Rameshwar (2003) who reported that the yield attributing characters and yield of pigeonpea were higher with foliar spray of 1AA + boron + zinc and least impact was observed in IAA and micronutrients spray alone. The combination of nutrient levels and growth regulators helps to sustain the yield of transplanted pigeonpea with higher productivity.

Significantly higher grain yield (18\%) was recorded with application of 37.5:75 N: $\mathrm{P}_{2} \mathrm{O}_{5}$ $\mathrm{kg}$ per ha along with foliar spray of salicylic acid $(0.02 \%)+\mathrm{ZnSO}_{4}(0.5 \%)+$ soluble boron $(0.2 \%)$ as compared to recommended practice (single control). The former treatment has noticed 13 per cent higher grain yield over single control with application of 37.5:75 N: $\mathrm{P}_{2} \mathrm{O}_{5} \mathrm{~kg}$ per ha along with foliar spray of $\mathrm{ZnSO}_{4}(0.5 \%)+$ soluble boron $(0.2$ $\%)$. Whereas it was 10 per cent higher grain yield with application of 37.5:75 $\mathrm{N}: \mathrm{P}_{2} \mathrm{O}_{5} \mathrm{~kg}$ per ha along with foliar spray of salicylic acid $(0.02 \%)+\mathrm{ZnSO}_{4}(0.5 \%)+$ soluble boron $(0.2 \%)$ over single control (Table 1$)$.

Significantly higher husk and stalk yield (13012 $\mathrm{kg} \mathrm{ha}^{-1}$ ) was recorded with application of 50:100 N: $\mathrm{P}_{2} \mathrm{O}_{5} \mathrm{~kg}$ per ha along with foliar spray of salicylic acid $(0.02 \%)+\mathrm{ZnSO}_{4}(0.5$ $\%)+$ soluble boron $(0.2 \%)$ when compared to single control. Significantly lower stalk and husk yield was recorded with application of 25:50 N: $\mathrm{P}_{2} \mathrm{O}_{5} \mathrm{~kg}$ per ha without foliar spray $\left(8066 \mathrm{~kg} \mathrm{ha}^{-1}\right.$ ) and application of $37.5: 75$ $\mathrm{N}: \mathrm{P}_{2} \mathrm{O}_{5} \mathrm{~kg}$ per ha without foliar spray $(8,553$ $\mathrm{kg} \mathrm{ha}^{-1}$ ) and on par results were obtained with 
all the remaining treatment combinations (Table 1).

Effect of nutrient levels and growth regulators on number of root nodules and leaf litter fall of transplanted pigeonpea

Significantly higher number of root nodules per plant was recorded with application of 37.5:75 N: $\mathrm{P}_{2} \mathrm{O}_{5} \mathrm{~kg}$ per hectare and 50:100 $\mathrm{N}: \mathrm{P}_{2} \mathrm{O}_{5} \mathrm{~kg}$ per hectare along with foliar spray of micronutrients and growth regulators, foliar spray of micronutrients alone and without spray when compared to single control. Application of 25:50 N: $\mathrm{P}_{2} \mathrm{O}_{5} \mathrm{~kg}$ per hectare along with foliar spray of micronutrients and growth regulators and without spray of micronutrients and growth regulators showed on par results (Table 1).

Significantly higher leaf litter fall per hectare was recorded with application of 37.5:75 $\mathrm{N}: \mathrm{P}_{2} \mathrm{O}_{5} \mathrm{~kg}$ per hectare and 50:100 N: $\mathrm{P}_{2} \mathrm{O}_{5} \mathrm{~kg}$ per hectare along with foliar spray of micronutrients and growth regulators, foliar spray of micronutrients alone and without spray when compared to single control. Application of $25: 50 \mathrm{~N}: \mathrm{P}_{2} \mathrm{O}_{5} \mathrm{~kg}$ per hectare along with foliar spray of salicylic acid $(0.02$ $\%)+\mathrm{ZnSO}_{4}(0.5 \%)+$ soluble boron $(0.2 \%)$, foliar spray of micronutrients alone and without spray recorded on par results (Table 1).

Effect of nutrient levels and growth regulators on plant nutrient content and uptake of nutrients

Nutrient content in any crops is not only dependent on the growth and development of crops but also the concentration of various nutrients. Therefore, the quantum of nutrient uptake is largely determined by the total biological yield. Results in the present study revealed that $50: 100 \mathrm{~N}: \mathrm{P}_{2} \mathrm{O}_{5} \mathrm{~kg}$ per ha recorded significantly higher nitrogen $(0.97 \%$ and $\left.139.0 \mathrm{~kg} \mathrm{ha}^{-1}\right)$, phosphorus $(0.08 \%$ and $\left.10.8 \mathrm{~kg} \mathrm{ha}^{-1}\right)$ and potassium $(0.48 \%$ and 39.0 $\left.\mathrm{kg} \mathrm{ha}{ }^{-1}\right)$ at 90 days after transplanting and higher nitrogen $\left(2.5 \%\right.$ and $\left.360.5 \mathrm{~kg} \mathrm{ha}^{-1}\right)$, phosphorus $\left(0.27 \%\right.$ and $\left.38.9 \mathrm{~kg} \mathrm{ha}^{-1}\right)$ and potassium $\left(0.84 \%\right.$ and $\left.116.8 \mathrm{~kg} \mathrm{ha}^{-1}\right)$ content and uptake by crop at harvest and it was on par with application of 37.5:75 N: $\mathrm{P}_{2} \mathrm{O}_{5} \mathrm{~kg}$ per ha. Whereas, the treatment receiving $25: 50 \mathrm{~kg}$ $\mathrm{ha}^{-1}$ recorded significantly lower nutrient content and nutrient uptake at all the stages of crop growth (Table 2). Pulse crops are endowed with unique property of fixing atmospheric nitrogen in amount greater than their own requirements but the availability of other nutrients especially $\mathrm{P}$ is important for pulse production which is to be supplied externally. These results were supported by in hybrid pigeonpea.

This confirms the findings of Singh et al., (2016) and Sudhir (2010) where application of 200 per cent recommended dose of fertilizer (40:80:40:40 N: $\mathrm{P}_{2} \mathrm{O}_{5}: \mathrm{K}_{2} \mathrm{O}: \mathrm{S} \mathrm{kg} \mathrm{ha}^{-1}$ ) significantly increased total uptake of $\mathrm{N}$ (108.16 kg ha $\left.{ }^{-1}\right), \mathrm{P}_{2} \mathrm{O}_{5}\left(8.3 \mathrm{~kg} \mathrm{ha}^{-1}\right), \mathrm{K}_{2} \mathrm{O}$ $\left(98.1 \mathrm{~kg} \mathrm{ha}^{-1}\right)$ and $\mathrm{S}\left(25.2 \mathrm{~kg} \mathrm{ha}^{-1}\right)$ in hybrid pigeonpea. But it was statistically at par with 150 per cent RDF (30:60:30:30 $\mathrm{N}: \mathrm{P}_{2} \mathrm{O}_{5}: \mathrm{K}_{2} \mathrm{O}: \mathrm{S} \mathrm{kg} \mathrm{ha}^{-1}$ ). Singh et al., (2006) and Srivastava and Srivastava (1993) also reported the similar results in pigeonpea by increasing the nutrient levels upto 150 and 200 per cent RDF.

Nutrient uptake of transplanted pigeonpea showed significant results as influenced by foliar spray of micronutrients and growth regulators. At 90 DAT, significantly higher nitrogen uptake (129.5 $\left.\mathrm{kg} \mathrm{ha}^{-1}\right)$, phosphorus uptake $\left(9.7 \mathrm{~kg} \mathrm{ha}^{-1}\right)$ and potassium $(43.5 \mathrm{~kg}$ $\mathrm{ha}^{-1}$ ) was recorded with foliar spray of salicylic acid $(0.02 \%)+\mathrm{ZnSO}_{4}(0.5 \%)+$ soluble boron $(0.2 \%)$ as compared to without spray. At harvest, significantly higher phosphorus uptake (38.3 $\left.\mathrm{kg} \mathrm{ha}^{-1}\right)$ and 
potassium uptake $\left(117.5 \mathrm{~kg} \mathrm{ha}^{-1}\right)$ was recorded with foliar spray of salicylic acid $(0.02 \%)+\mathrm{ZnSO}_{4}(0.5 \%)+$ soluble boron $(0.2 \%)$ as compared to without spray (Table 2). Foliar spray of $\mathrm{ZnSO}_{4}+$ soluble boron $(0.2$ $\%)$ and foliar spray of NAA $(0.05 \%)+$ $\mathrm{ZnSO}_{4}+$ soluble boron $(0.2 \%)$ and foliar spray of $\mathrm{ZnSO}_{4}(0.5 \%)+$ soluble boron $(0.2$ $\%)$ recorded on par results. Significantly higher nitrogen uptake (335.1 $\mathrm{kg} \mathrm{ha}^{-1}$ ) at harvest was recorded with foliar spray of $\mathrm{ZnSO}_{4}+$ soluble boron $(0.2 \%)$ followed by foliar spray of $\mathrm{ZnSO}_{4}(0.5 \%)+$ soluble boron $(0.2 \%)$ and foliar spray of NAA $(0.05 \%)+$ $\mathrm{ZnSO}_{4}(0.5 \%)+$ soluble boron $(0.2 \%)$.

Zinc uptake at 90 DAT (Table 3) showed non significant results as influenced by nutrient levels, foliar spray of micronutrients and growth regulators alone, their interactions and comparison with single control. At harvest significantly higher zinc uptake (71.8 $\left.\mathrm{g} \mathrm{ha}^{-1}\right)$ was recorded with application of 25:50 $\mathrm{N}: \mathrm{P}_{2} \mathrm{O}_{5} \mathrm{~kg}$ per ha. Application of 37.5:75 $\mathrm{N}: \mathrm{P}_{2} \mathrm{O}_{5} \mathrm{~kg}$ per ha showed on par results and significantly lower zinc uptake was recorded with application of $50: 100 \mathrm{~N}: \mathrm{P}_{2} \mathrm{O}_{5} \mathrm{~kg}$ per ha. There was decrease in zinc uptake with the increase in phosphorus levels, the main reason behind this is that there exist an antagonistic relationship between applied phosphorus and zinc, there by reduces the zinc content and uptake in grain and straw of transplanted pigeonpea (Table 3). These results are in conformity with the findings of Devrajan et al., (1980) and Amin et al., (2014) where application of increased doses of nitrogen and phosphorus decreased the uptake of zinc. The plants which were sprayed with soluble boron have recorded higher boron uptake (Table 3). Foliar application of boron increased the uptake of boron as the foliar application is a simple way for making quick correction of plant nutritional status due to which growth and uptake of nutrient increased in transplanted pigeonpea (Habib, 2012).
Among the foliar spray of micronutrients and growth regulators, non significant results were obtained at 90 DAT with respect to boron uptake. At harvest, higher boron uptake (Table 3) was recorded with foliar spray of salicylic acid $(0.02 \%)+\mathrm{ZnSO}_{4}(0.5 \%)+$ soluble boron $(0.2 \%)$, foliar spray of NAA $(0.05 \%)+\mathrm{ZnSO}_{4}(0.5 \%)+$ soluble boron $(0.2 \%)$, foliar spray $\mathrm{ZnSO}_{4}(0.5 \%)+$ soluble boron $(0.2 \%)$ as compared to no spray.

\section{Effect of nutrient levels and growth regulators on nutrient content in the soil}

The nutrient content in the soil after harvest of crop (Table 3) differed significantly as influenced by nutrient levels. Application of 50:100 N: $\mathrm{P}_{2} \mathrm{O}_{5} \quad \mathrm{~kg}$ per ha recorded significantly higher organic carbon content $\left(5.4 \mathrm{~g} \mathrm{~kg}^{-1}\right)$, available nitrogen $\left(266.3 \mathrm{~kg} \mathrm{ha}^{-1}\right)$, available phosphorus (29.6 $\left.\mathrm{kg} \mathrm{ha}^{-1}\right)$ and available potassium in soil $\left(231.5 \mathrm{~kg} \mathrm{ha}^{-1}\right)$ as compared to application of $25: 50 \mathrm{~N}: \mathrm{P}_{2} \mathrm{O}_{5} \mathrm{~kg}$ per ha and with application of 37.5:75 N: $\mathrm{P}_{2} \mathrm{O}_{5}$ $\mathrm{kg}$ per ha. The soil organic carbon content $\left(5.3 \mathrm{~g} \mathrm{~kg}^{-1}\right)$, available nitrogen $\left(258.9 \mathrm{~kg} \mathrm{ha}^{-1}\right)$, available phosphorus (28.9 $\left.\mathrm{kg} \mathrm{ha}^{-1}\right)$ and available potassium in soil $\left(230.6 \mathrm{~kg} \mathrm{ha}^{-1}\right) \mathrm{did}$ not differ significantly. Similar findings were reported by Raju et al., (1991) in chickpea who recorded higher nutrient status of soil after harvest due to the application of increasing levels of nutrients.

\section{Interactions between nutrient levels and foliar spray of micronutrients and growth regulators}

Among the interactions, Significantly higher nitrogen uptake $\left(157.5 \mathrm{~kg} \mathrm{ha}^{-1}\right)$ at $90 \mathrm{DAT}$ (Table 2) was recorded with application of $50: 100 \mathrm{~N}: \mathrm{P}_{2} \mathrm{O}_{5} \mathrm{~kg}$ per ha along with foliar spray of salicylic acid $(0.02 \%)+\mathrm{ZnSO}_{4}(0.5$ $\%)+$ soluble boron $(0.2 \%)$ when compared to single control. 
Table.1 Number of root nodules per plant, leaf litter fall, grain yield, husk and stalk yield of transplanted pigeonpea as influenced by different nutrient levels and growth regulators

\begin{tabular}{|c|c|c|c|c|c|c|}
\hline \multirow[t]{2}{*}{ Treatments } & \multicolumn{2}{|c|}{$\begin{array}{c}\text { Number of root nodules per } \\
\text { plant }\end{array}$} & \multicolumn{2}{|c|}{ Leaf litter fall $\left(\mathrm{kg} \mathrm{ha}^{-1}\right)$} & \multirow[t]{2}{*}{$\begin{array}{l}\text { Grain yield } \\
\left.\text { (kg ha }^{-1}\right)\end{array}$} & \multirow{2}{*}{$\begin{array}{c}\text { Husk and } \\
\text { stalk yield } \\
\left(\mathrm{kg} \mathrm{ha}^{-1}\right)\end{array}$} \\
\hline & 60 DAT & 90 DAT & 90 DAT & 120 DAT & & \\
\hline \multicolumn{7}{|c|}{ Nutrient levels $(\mathbf{N})$} \\
\hline $\mathbf{N}_{1}$ & $23.5^{b}$ & $185.1^{\mathrm{b}}$ & $508.7^{\mathrm{b}}$ & $836.3^{\mathrm{a}}$ & $2,673^{b}$ & $9,701^{\mathrm{b}}$ \\
\hline $\mathbf{N}_{2}$ & $28.2^{\mathrm{a}}$ & $217.4^{\mathrm{a}}$ & $586.4^{\mathrm{a}}$ & $922.3^{\mathrm{a}}$ & $2,958^{\mathrm{a}}$ & $10,881^{\mathrm{ab}}$ \\
\hline $\mathbf{N}_{3}$ & $28.9^{\mathrm{a}}$ & $218.8^{\mathrm{a}}$ & $587.7^{\mathrm{a}}$ & $906.8^{\mathrm{a}}$ & $2,908^{\mathrm{ab}}$ & $11,511^{\mathrm{a}}$ \\
\hline S.Em. \pm & 0.38 & 5.45 & 16.08 & 21.85 & 68 & 381 \\
\hline \multicolumn{7}{|c|}{ Foliar application of growth regulators and micronutrients (F) } \\
\hline $\mathbf{F}_{1}$ & $26.8^{\mathrm{a}}$ & $204.5^{\mathrm{a}}$ & $551.7^{\mathrm{a}}$ & $875.8^{\mathrm{b}}$ & $2,809^{\mathrm{b}}$ & $10,919^{\mathrm{a}}$ \\
\hline $\mathbf{F}_{2}$ & $27.3^{\mathrm{a}}$ & $210.5^{\mathrm{a}}$ & $567.8^{\mathrm{a}}$ & $1007.8^{\mathrm{a}}$ & $3,230^{\mathrm{a}}$ & $11,506^{\mathrm{a}}$ \\
\hline $\mathbf{F}_{3}$ & $26.3^{\mathrm{a}}$ & $205.8^{\mathrm{a}}$ & $559.2^{\mathrm{a}}$ & $951.3^{\mathrm{ab}}$ & $3,039^{\mathrm{ab}}$ & $11,161^{\mathrm{a}}$ \\
\hline $\mathbf{F}_{4}$ & $26.9^{\mathrm{a}}$ & $207.7^{\mathrm{a}}$ & $564.9^{\mathrm{a}}$ & $719.4^{c}$ & $2,307^{\mathrm{c}}$ & $9,205^{\mathrm{a}}$ \\
\hline S.Em. \pm & 0.78 & 5.52 & 16.38 & 27.92 & 90 & 557 \\
\hline \multicolumn{7}{|c|}{ Interaction $(\mathbf{N} \times \mathbf{F})$} \\
\hline $\mathbf{N}_{1} \mathbf{F}_{1}$ & $22.9^{d}$ & $176.8^{\mathrm{c}}$ & $477.0^{\mathrm{b}}$ & $851.8^{\mathrm{cd}}$ & $2,732^{\text {cd }}$ & $10,215^{\mathrm{a}-\mathrm{c}}$ \\
\hline $\mathbf{N}_{1} \mathbf{F}_{2}$ & $24.5^{\mathrm{b}-\mathrm{d}}$ & $188.9^{\mathrm{bc}}$ & $509.6^{\mathrm{ab}}$ & $922.1^{\mathrm{b}-\mathrm{d}}$ & $2,957^{\mathrm{b}-\mathrm{d}}$ & $10,172^{\mathrm{a}-\mathrm{c}}$ \\
\hline $\mathbf{N}_{\mathbf{1}} \mathbf{F}_{3}$ & $22.6^{\mathrm{d}}$ & $186.9^{\mathrm{bc}}$ & $515.3^{\mathrm{ab}}$ & $917.5^{\mathrm{b}-\mathrm{d}}$ & $2,909^{b-d}$ & $10,352^{\mathrm{a}-\mathrm{c}}$ \\
\hline $\mathbf{N}_{1} \mathbf{F}_{4}$ & $23.8^{\mathrm{cd}}$ & $187.9^{\mathrm{bc}}$ & $532.9^{\mathrm{ab}}$ & $653.7^{\mathrm{e}}$ & $2,096^{\mathrm{e}}$ & $8,066^{c}$ \\
\hline $\mathbf{N}_{2} \mathbf{F}_{1}$ & $27.8^{\mathrm{a}-\mathrm{c}}$ & $214.3^{\mathrm{ab}}$ & $578.2^{\mathrm{a}}$ & $904.7^{\mathrm{b}-\mathrm{d}}$ & $2,902^{b-d}$ & $11,146^{\mathrm{ab}}$ \\
\hline $\mathbf{N}_{2} \mathbf{F}_{2}$ & $28.7^{\mathrm{ab}}$ & $221.3^{\mathrm{a}}$ & $597.0^{\mathrm{a}}$ & $1,086.4^{\mathrm{a}}$ & $3,484^{\mathrm{a}}$ & $11,333^{\mathrm{a}-\mathrm{c}}$ \\
\hline $\mathbf{N}_{2} \mathbf{F}_{3}$ & $27.9^{a-c}$ & $214.9^{\mathrm{ab}}$ & $579.6^{\mathrm{a}}$ & $1,040.8^{\mathrm{ab}}$ & $3,338^{\mathrm{ab}}$ & $12,172^{\mathrm{a}}$ \\
\hline $\mathbf{N}_{2} \mathbf{F}_{4}$ & $28.4^{\mathrm{ab}}$ & $219.0^{\mathrm{ab}}$ & $590.7^{a}$ & $657.3^{\mathrm{e}}$ & $2,108^{e}$ & $8,553^{\mathrm{bc}}$ \\
\hline $\mathbf{N}_{\mathbf{3}} \mathbf{F}_{\mathbf{1}}$ & $29.7^{\mathrm{a}}$ & $222.3^{\mathrm{a}}$ & $599.7^{\mathrm{a}}$ & $870.9^{\text {cd }}$ & $2,793^{\text {cd }}$ & $11,078^{\mathrm{a}-\mathrm{c}}$ \\
\hline $\mathbf{N}_{3} \mathbf{F}_{2}$ & $28.7^{\mathrm{ab}}$ & $221.3^{\mathrm{a}}$ & $597.0^{\mathrm{a}}$ & $1,013.4^{a-c}$ & $3,249^{a-c}$ & $13,012^{\mathrm{a}}$ \\
\hline $\mathbf{N}_{\mathbf{3}} \mathbf{F}_{\mathbf{3}}$ & $28.5^{\mathrm{ab}}$ & $215.6^{\mathrm{ab}}$ & $582.7^{\mathrm{a}}$ & $895.6^{\mathrm{b}-\mathrm{d}}$ & $2,872^{\mathrm{b}-\mathrm{d}}$ & $10,958^{\mathrm{a}-\mathrm{c}}$ \\
\hline $\mathbf{N}_{3} \mathbf{F}_{4}$ & $28.5^{\mathrm{ab}}$ & $216.1^{\mathrm{ab}}$ & $571.3^{\mathrm{a}}$ & $847.2^{\mathrm{d}}$ & $2,717^{\mathrm{d}}$ & $10,995^{\mathrm{a}-\mathrm{c}}$ \\
\hline S.Em. \pm & 1.35 & 9.56 & 28.38 & 48.36 & 155 & 965 \\
\hline \multicolumn{7}{|c|}{ Single control (SC) } \\
\hline SC & 22.90 & 182.74 & 510.99 & 914.77 & 2,933 & 10,646 \\
\hline S.Em. \pm & 1.26 & 9.48 & 28.03 & 46.91 & 150 & 913 \\
\hline LSD (0.05) & 3.69 & 27.67 & 81.82 & 136.91 & 438 & NS \\
\hline $\begin{array}{l}\mathrm{N}=\mathrm{Nl} \\
\mathrm{N}_{1}=2 \\
\mathrm{~N}_{2}=3 \\
\mathrm{~N}_{3}=5 \\
\\
\mathrm{SC}(\mathrm{I} \\
\mathrm{NS}=\end{array}$ & $\begin{array}{l}\text { ient levels } \\
50 \mathrm{~N}: \mathrm{P}_{2} \mathrm{O}_{5} \mathrm{~kg} \mathrm{ha}^{-1} \\
5: 75 \mathrm{~N}: \mathrm{P}_{2} \mathrm{O}_{5} \mathrm{~kg} \mathrm{ha}^{-1} \\
100 \mathrm{~N}: \mathrm{P}_{2} \mathrm{O}_{5} \mathrm{~kg} \mathrm{ha}^{-1} \\
\\
\mathrm{P})=\text { Single control ( } \\
\text { on significant; DAT= }\end{array}$ & $\begin{array}{r}\mathrm{F}=\text { Foliar appl } \\
\mathrm{F}_{1}=\mathrm{NAAA}(0 . \\
\mathrm{F}_{2}=\text { Salicylic a } \\
\mathrm{F}_{3}=\mathrm{ZnSO}_{4}( \\
\mathrm{F}_{4}=\text { Control }( \\
\text { tha }^{-1}+25: 50 \mathrm{~N} \\
\text { after transplant }^{-1}\end{array}$ & $\begin{array}{l}\mathrm{n} \text { of growth re } \\
+\mathrm{ZnSO}_{4}(0.5 \\
02 \%)+\mathrm{ZnSO} \\
)+ \text { soluble bor } \\
\text { owth regulator } \\
\mathrm{kg} \mathrm{ha}^{-1}+\mathrm{ZnS}\end{array}$ & $\begin{array}{l}\text { and micronutri } \\
\text { luble boron }(0 . \\
)+ \text { soluble bor } \\
\%) \\
\text { cronutrients }) \\
\text { ha }^{-1}+\text { soluble }\end{array}$ & $\begin{array}{l}2 \%) \\
\left.2.5 \mathrm{~kg} \mathrm{ha}^{-1}\right)\end{array}$ & \\
\hline
\end{tabular}


Table.2 Nutrient content and nutrient uptake of transplanted pigeonpea as influenced by different nutrient levels and growth regulators

\begin{tabular}{|c|c|c|c|c|c|c|c|c|c|c|c|c|}
\hline \multirow[t]{3}{*}{ Treatments } & \multicolumn{6}{|c|}{ Nutrient content at } & \multicolumn{6}{|c|}{ Nutrient uptake at } \\
\hline & \multicolumn{3}{|c|}{90 DAT } & \multicolumn{3}{|c|}{ Harvest } & \multicolumn{3}{|c|}{90 DAT } & \multicolumn{3}{|c|}{ Harvest } \\
\hline & $\mathbf{N}(\%)$ & $\mathbf{P}(\%)$ & $\mathbf{K}(\%)$ & $\mathbf{N}(\%)$ & $\mathbf{P}(\%)$ & $\mathrm{K}(\%)$ & $\mathbf{N}\left(\mathrm{kg} \mathrm{ha}^{-1}\right)$ & $P\left(\mathrm{~kg} \mathrm{ha}^{-1}\right)$ & K $\left(\mathrm{kg} \mathrm{ha}^{-1}\right)$ & $\mathbf{N}\left(\mathrm{kg} \mathrm{ha}^{-1}\right)$ & P $\left(\mathrm{kg} \mathrm{ha}^{-1}\right)$ & $\mathrm{K}\left(\mathrm{kg} \mathrm{ha}^{-1}\right)$ \\
\hline \multicolumn{13}{|c|}{ Nutrient levels $(\mathbf{N})$} \\
\hline $\mathbf{N}_{1}$ & $0.75^{\mathrm{b}}$ & $0.06^{\mathrm{c}}$ & $0.57^{\mathrm{a}}$ & $1.98^{\mathrm{b}}$ & $0.24^{\mathrm{c}}$ & $0.71^{b}$ & $93.1^{b}$ & $6.9^{b}$ & $39.6^{b}$ & $245.0^{b}$ & $29.7^{b}$ & $87.3^{b}$ \\
\hline $\mathbf{N}_{2}$ & $0.89^{\mathrm{ab}}$ & $0.07^{b}$ & $0.59^{\mathrm{a}}$ & $2.43^{\mathrm{ab}}$ & $0.25^{\mathrm{ab}}$ & $0.81^{\mathrm{a}}$ & $123.1^{\mathrm{a}}$ & $9.2^{\mathrm{ab}}$ & $47.6^{\mathrm{a}}$ & $336.3^{\mathrm{a}}$ & $34.6^{\mathrm{ab}}$ & $115.7^{\mathrm{ab}}$ \\
\hline $\mathbf{N}_{3}$ & $0.97^{\mathrm{a}}$ & $0.08^{\mathrm{a}}$ & $0.48^{\mathrm{b}}$ & $2.5^{\mathrm{a}}$ & $0.27^{\mathrm{a}}$ & $0.84^{\mathrm{a}}$ & $139.0^{\mathrm{a}}$ & $10.8^{\mathrm{a}}$ & $39.0^{\mathrm{b}}$ & $360.5^{\mathrm{a}}$ & $38.9^{\mathrm{a}}$ & $116.8^{\mathrm{a}}$ \\
\hline S.Em. \pm & 0.003 & 0.003 & 0.04 & 0.08 & 0.02 & 0.002 & 11.7 & 0.3 & 1.2 & 12.1 & 1.2 & 3.2 \\
\hline \multicolumn{13}{|c|}{ Foliar application of growth regulators and micronutrients $(\mathbf{F})$} \\
\hline $\mathbf{F}_{1}$ & $0.87^{\mathrm{a}}$ & $0.07^{\mathrm{a}}$ & $0.57^{\mathrm{a}}$ & $2.38^{\mathrm{a}}$ & $0.26^{\mathrm{a}}$ & $0.79^{\mathrm{a}}$ & $120.1^{\mathrm{ab}}$ & $9.0^{\mathrm{ab}}$ & $42.9^{\mathrm{ab}}$ & $326.7^{\mathrm{ab}}$ & $35.7^{\mathrm{ab}}$ & $107.8^{\mathrm{ab}}$ \\
\hline $\mathbf{F}_{2}$ & $0.87^{\mathrm{a}}$ & $0.07^{\mathrm{a}}$ & $0.56^{\mathrm{a}}$ & $2.22^{\mathrm{a}}$ & $0.26^{\mathrm{a}}$ & $0.80^{\mathrm{a}}$ & $129.5^{\mathrm{a}}$ & $9.7^{\mathrm{a}}$ & $43.5^{\mathrm{a}}$ & $327.1^{\mathrm{ab}}$ & $38.3^{\mathrm{a}}$ & $117.5^{\mathrm{a}}$ \\
\hline $\mathbf{F}_{3}$ & $0.87^{\mathrm{a}}$ & $0.07^{\mathrm{a}}$ & $0.56^{\mathrm{a}}$ & $2.36^{\mathrm{a}}$ & $0.26^{\mathrm{a}}$ & $0.78^{\mathrm{a}}$ & $123.2^{\mathrm{ab}}$ & $9.5^{\mathrm{ab}}$ & $43.4^{\mathrm{ab}}$ & $335.1^{\mathrm{a}}$ & $36.9^{\mathrm{ab}}$ & $111.1^{\mathrm{ab}}$ \\
\hline $\mathbf{F}_{4}$ & $0.87^{\mathrm{a}}$ & $0.07^{\mathrm{a}}$ & $0.49^{\mathrm{a}}$ & $2.27^{\mathrm{a}}$ & $0.25^{\mathrm{a}}$ & $0.79^{\mathrm{a}}$ & $100.9^{b}$ & $7.7^{\mathrm{b}}$ & $38.5^{b}$ & $261.3^{b}$ & $28.8^{b}$ & $90.4^{b}$ \\
\hline S.Em. \pm & 0.008 & 0.002 & 0.02 & 0.10 & 0.01 & 0.005 & 14.9 & 0.53 & 1.55 & 23.8 & 2.4 & 3.7 \\
\hline \multicolumn{13}{|c|}{ Interaction $(\mathbf{N} \times \mathbf{F})$} \\
\hline $\mathbf{N}_{1} \mathbf{F}_{1}$ & $0.76^{\mathrm{e}}$ & $0.06^{\mathrm{a}}$ & $0.66^{\mathrm{a}}$ & $2.10^{b}$ & $0.26^{\mathrm{a}}$ & $0.71^{b}$ & $97.9^{c}$ & $7.4^{b-d}$ & $43.9^{\mathrm{ab}}$ & $271.9^{b-d}$ & $33.7^{b-d}$ & $91.5^{b-d}$ \\
\hline $\mathbf{N}_{1} \mathbf{F}_{2}$ & $0.75^{\mathrm{c}}$ & $0.06^{\mathrm{a}}$ & $0.64^{\mathrm{ab}}$ & $1.90^{\mathrm{b}}$ & $0.24^{b}$ & $0.70^{\mathrm{b}}$ & $98.4^{\mathrm{c}}$ & $7.5^{\mathrm{b}-\mathrm{d}}$ & $45.0^{\mathrm{ab}}$ & $249.5^{\mathrm{cd}}$ & $31.5^{\mathrm{cd}}$ & $91.9^{b-d}$ \\
\hline $\mathbf{N}_{1} \mathbf{F}_{3}$ & $0.75^{\mathrm{c}}$ & $0.06^{\mathrm{a}}$ & $0.55^{\mathrm{b}}$ & $2.00^{\mathrm{b}}$ & $0.25^{b}$ & $0.70^{\mathrm{b}}$ & $99.1^{\mathrm{c}}$ & $7.3^{b-d}$ & $39.0^{\mathrm{b}}$ & $265.2^{b-d}$ & $33.2^{b-d}$ & $92.9^{b-d}$ \\
\hline $\mathbf{N}_{1} \mathbf{F}_{4}$ & $0.76^{\mathrm{d}}$ & $0.05^{\mathrm{a}}$ & $0.41^{\mathrm{c}}$ & $1.93^{b}$ & $0.24^{b}$ & $0.72^{\mathrm{b}}$ & $77.0^{c}$ & $5.5^{\mathrm{d}}$ & $30.6^{\mathrm{b}}$ & $196.1^{d}$ & $24.4^{\mathrm{d}}$ & $72.9^{d}$ \\
\hline $\mathbf{N}_{2} \mathbf{F}_{1}$ & $0.89^{\mathrm{c}}$ & $0.07^{\mathrm{a}}$ & $0.61^{\mathrm{ab}}$ & $2.41^{\mathrm{ab}}$ & $0.25^{\mathrm{a}}$ & $0.85^{\mathrm{a}}$ & $127.6^{\mathrm{b}}$ & $9.7^{\mathrm{a}-\mathrm{c}}$ & $49.0^{\mathrm{ab}}$ & $338.6^{\mathrm{ab}}$ & $35.1^{a-c}$ & $119.5^{\mathrm{a}-\mathrm{c}}$ \\
\hline $\mathbf{N}_{2} \mathbf{F}_{2}$ & $0.89^{b}$ & $0.07^{\mathrm{a}}$ & $0.62^{\mathrm{ab}}$ & $2.52^{\mathrm{ab}}$ & $0.27^{\mathrm{a}}$ & $0.84^{\mathrm{a}}$ & $132.5^{\mathrm{ab}}$ & $10.1^{\mathrm{a}-\mathrm{c}}$ & $51.1^{\mathrm{a}}$ & $373.4^{\mathrm{ab}}$ & $40.0^{\mathrm{ab}}$ & $124.6^{\mathrm{ab}}$ \\
\hline $\mathbf{N}_{2} \mathbf{F}_{3}$ & $0.89^{\mathrm{b}}$ & $0.06^{\mathrm{a}}$ & $0.69^{\mathrm{a}}$ & $2.44^{\mathrm{ab}}$ & $0.24^{\mathrm{a}}$ & $0.84^{\mathrm{a}}$ & $137.6^{\mathrm{ab}}$ & $9.8^{\mathrm{a}-\mathrm{c}}$ & $55.8^{\mathrm{a}}$ & $378.4^{\mathrm{a}}$ & $37.2^{\mathrm{ab}}$ & $129.8^{\mathrm{ab}}$ \\
\hline $\mathbf{N}_{2} \mathbf{F}_{4}$ & $0.89^{\mathrm{b}}$ & $0.07^{\mathrm{a}}$ & $0.42^{c}$ & $2.37^{\mathrm{ab}}$ & $0.25^{\mathrm{a}}$ & $0.83^{\mathrm{a}}$ & $94.6^{c}$ & $7.2^{\mathrm{cd}}$ & $34.7^{b}$ & $252.7^{\mathrm{cd}}$ & $26.7^{\mathrm{cd}}$ & $88.9^{\text {cd }}$ \\
\hline $\mathbf{N}_{3} \mathbf{F}_{1}$ & $0.97^{\mathrm{b}}$ & $0.07^{\mathrm{a}}$ & $0.43^{c}$ & $2.62^{\mathrm{a}}$ & $0.26^{\mathrm{a}}$ & $0.81^{\mathrm{a}}$ & $134.6^{\mathrm{ab}}$ & $9.9^{\mathrm{a}-\mathrm{c}}$ & $36.0^{b}$ & $363.4^{\mathrm{ab}}$ & $36.1^{\mathrm{a}-\mathrm{c}}$ & $112.4^{\mathrm{a}-\mathrm{c}}$ \\
\hline $\mathbf{N}_{3} \mathbf{F}_{2}$ & $0.97^{\mathrm{a}}$ & $0.07^{\mathrm{a}}$ & $0.42^{c}$ & $2.23^{\mathrm{a}}$ & $0.26^{\mathrm{a}}$ & $0.83^{\mathrm{a}}$ & $157.5^{\mathrm{a}}$ & $11.6^{\mathrm{a}}$ & $34.5^{b}$ & $362.6^{\mathrm{ab}}$ & $42.3^{\mathrm{a}}$ & $134.9^{\mathrm{a}}$ \\
\hline $\mathbf{N}_{3} \mathbf{F}_{3}$ & $0.96^{\mathrm{a}}$ & $0.08^{\mathrm{a}}$ & $0.44^{c}$ & $2.63^{\mathrm{a}}$ & $0.28^{\mathrm{a}}$ & $0.80^{\mathrm{a}}$ & $133.0^{\mathrm{ab}}$ & $11.3^{\mathrm{a}}$ & $35.4^{\mathrm{b}}$ & $363.7^{\mathrm{ab}}$ & $38.7^{\mathrm{a}-\mathrm{c}}$ & $110.5^{\mathrm{a}-\mathrm{c}}$ \\
\hline $\mathbf{N}_{3} \mathbf{F}_{4}$ & $0.96^{\mathrm{a}}$ & $0.08^{\mathrm{a}}$ & $0.63^{b}$ & $2.50^{\mathrm{a}}$ & $0.27^{\mathrm{a}}$ & $0.80^{\mathrm{a}}$ & $131.0^{\mathrm{ab}}$ & $10.4^{\mathrm{ab}}$ & $50.2^{\mathrm{a}}$ & $342.8^{\mathrm{ab}}$ & $37.0^{\mathrm{a}-\mathrm{c}}$ & $109.2^{\mathrm{a}-\mathrm{c}}$ \\
\hline S.Em. \pm & 0.01 & 0.004 & 0.04 & 0.17 & 0.02 & 0.02 & 8.73 & 0.92 & 2.68 & 41.19 & 3.12 & 8.33 \\
\hline \multicolumn{13}{|c|}{ Single control (SC) } \\
\hline SC & 0.77 & 0.06 & 0.64 & 2.43 & 0.22 & 0.70 & 104.7 & 7.7 & 45.7 & 330.0 & 29.9 & 95.2 \\
\hline S.Em. \pm & 0.01 & 0.004 & 0.04 & 0.20 & 0.03 & 0.01 & 8.2 & 0.8 & 2.68 & 37.91 & 3.2 & 8.18 \\
\hline LSD (0.05) & 0.04 & 9.25 & 0.11 & NS & NS & 0.03 & 23.9 & 2.4 & 7.8 & 110.6 & 9.2 & 23.9 \\
\hline \multicolumn{13}{|c|}{$\begin{array}{lc}\mathrm{N}=\text { Nutrient levels } & \mathrm{F}=\text { Foliar application of growth regulators and micronutrients } \\
\mathrm{N}_{1}=25: 50 \mathrm{~N}: \mathrm{P}_{2} \mathrm{O}_{5} \mathrm{~kg} \mathrm{ha}^{-1} & \mathrm{~F}_{1}=\mathrm{NAA}(0.05 \%)+\mathrm{ZnSO}_{4}(0.5 \%)+\text { soluble boron }(0.2 \%) \\
\mathrm{N}_{2}=37.5: 75 \mathrm{~N}: \mathrm{P}_{2} \mathrm{O}_{5} \mathrm{~kg} \mathrm{ha}^{-1} & \mathrm{~F}_{2}=\mathrm{Salicylic} \text { acid }(0.02 \%)+\mathrm{ZnSO}_{4}(0.5 \%)+\text { soluble boron }(0.2 \%) \\
\mathrm{N}_{3}=50: 100 \mathrm{~N}: \mathrm{P}_{2} \mathrm{O}_{5} \mathrm{~kg} \mathrm{ha}^{-1} & \mathrm{~F}_{3}=\mathrm{ZnSO}_{4}(0.5 \%)+\text { soluble boron }(0.2 \%) \\
& \mathrm{F}_{4}=\text { Control (No growth regulators and micronutrients) } \\
\left.\text { SC (RPP)=Single control (FYM } 6 \mathrm{t} \mathrm{ha}^{-1}+25: 50 \mathrm{~N}: \mathrm{P}_{2} \mathrm{O}_{5} \mathrm{~kg} \mathrm{ha}^{-1}+\mathrm{ZnSO}_{4} 15 \mathrm{~kg} \mathrm{ha}^{-1}+\text { soluble boron } 2.5 \mathrm{~kg} \mathrm{ha}^{-1}\right) \\
\text { NS= Non significant; DAT= Days after transplanting }\end{array}$} \\
\hline
\end{tabular}


Table.3 Micronutrient uptake and nutrient content of soil of transplanted pigeonpea as influenced by different nutrient levels and growth regulators

\begin{tabular}{|c|c|c|c|c|c|c|c|c|}
\hline \multirow[t]{3}{*}{ Treatments } & \multicolumn{4}{|c|}{ Micronutrient uptake } & \multicolumn{4}{|c|}{ Nutrient content of soil after harvest } \\
\hline & \multicolumn{2}{|c|}{90 DAT } & \multicolumn{2}{|c|}{ Harvest } & \multirow[t]{2}{*}{$\mathrm{OC}\left(\mathrm{g} \mathrm{kg}^{-1}\right)$} & \multirow{2}{*}{ N $\left(\mathrm{kg} \mathrm{ha}^{-1}\right)$} & \multirow[t]{2}{*}{$P\left(\mathrm{~kg} \mathrm{ha}^{-1}\right)$} & \multirow[t]{2}{*}{$\mathrm{K}\left(\mathrm{kg} \mathrm{ha}^{-1}\right)$} \\
\hline & $\mathrm{Zn}\left(\mathrm{g} \mathrm{ha}^{-1}\right)$ & B $\left(\mathrm{g} \mathrm{ha}^{-1}\right)$ & $\operatorname{Zn}\left(\mathrm{g} \mathrm{ha}^{-1}\right)$ & B $\left(\mathrm{g} \mathrm{ha}^{-1}\right)$ & & & & \\
\hline \multicolumn{9}{|c|}{ Nutrient levels $(\mathbf{N})$} \\
\hline $\mathbf{N}_{1}$ & $25.5^{\mathrm{a}}$ & $33.9^{\mathrm{a}}$ & $71.8^{\mathrm{a}}$ & $76.1^{\mathrm{a}}$ & $5.0^{\mathrm{b}}$ & $240.6^{b}$ & $28.3^{\mathrm{b}}$ & $224.9^{\mathrm{ab}}$ \\
\hline $\mathbf{N}_{2}$ & $25.0^{\mathrm{a}}$ & $34.5^{\mathrm{a}}$ & $67.6^{\mathrm{ab}}$ & $79.1^{\mathrm{a}}$ & $5.3^{\mathrm{a}}$ & $258.9^{\mathrm{ab}}$ & $28.9^{\mathrm{ab}}$ & $230.6^{\mathrm{a}}$ \\
\hline $\mathbf{N}_{3}$ & $24.4^{\mathrm{a}}$ & $30.2^{\mathrm{a}}$ & $62.7^{b}$ & $75.2^{\mathrm{a}}$ & $5.4^{\mathrm{a}}$ & $266.3^{\mathrm{a}}$ & $29.6^{\mathrm{a}}$ & $231.5^{\mathrm{a}}$ \\
\hline S.Em. \pm & 0.63 & 2.13 & 2.29 & 1.24 & 0.1 & 2.82 & 0.22 & 1.96 \\
\hline \multicolumn{9}{|c|}{ Foliar application of growth regulators and micronutrients $(\mathrm{F})$} \\
\hline $\mathbf{F}_{1}$ & $25.2^{\mathrm{a}}$ & $33.4^{\mathrm{a}}$ & $73.4^{\mathrm{a}}$ & $83.3^{\mathrm{a}}$ & $5.1^{\mathrm{a}}$ & $258.1^{\mathrm{a}}$ & $28.9^{\mathrm{a}}$ & $227.9^{\mathrm{a}}$ \\
\hline $\mathbf{F}_{2}$ & $25.3^{\mathrm{a}}$ & $32.6^{\mathrm{a}}$ & $68.8^{\mathrm{a}}$ & $84.8^{\mathrm{a}}$ & $5.3^{\mathrm{a}}$ & $257.1^{\mathrm{a}}$ & $28.8^{\mathrm{a}}$ & $230.6^{\mathrm{a}}$ \\
\hline $\mathbf{F}_{3}$ & $25.0^{\mathrm{a}}$ & $33.6^{\mathrm{a}}$ & $73.2^{\mathrm{a}}$ & $82.5^{\mathrm{a}}$ & $5.3^{\mathrm{a}}$ & $257.6^{\mathrm{a}}$ & $28.9^{\mathrm{a}}$ & $230.4^{\mathrm{a}}$ \\
\hline $\mathbf{F}_{4}$ & $24.4^{\mathrm{a}}$ & $31.9^{\mathrm{a}}$ & $54.1^{\mathrm{a}}$ & $56.7^{b}$ & $5.2^{\mathrm{a}}$ & $260.4^{\mathrm{a}}$ & $29.1^{\mathrm{a}}$ & $230.7^{\mathrm{a}}$ \\
\hline S.Em. \pm & 0.57 & 1.23 & 1.95 & 2.90 & 0.04 & 4.82 & 0.37 & 3.35 \\
\hline \multicolumn{9}{|c|}{ Interaction $(\mathbf{N} \times \mathbf{F})$} \\
\hline $\mathbf{N}_{1} \mathbf{F}_{1}$ & $25.4^{\mathrm{a}}$ & $34.3^{\mathrm{ab}}$ & $73.5^{\mathrm{a}}$ & $81.0^{\mathrm{a}}$ & $4.8^{\mathrm{a}}$ & $250.5^{\mathrm{a}}$ & $28.3^{\mathrm{a}}$ & $216.8^{\mathrm{a}}$ \\
\hline $\mathbf{N}_{1} \mathbf{F}_{2}$ & $25.6^{\mathrm{a}}$ & $33.0^{\mathrm{ab}}$ & $74.9^{\mathrm{a}}$ & $83.9^{\mathrm{a}}$ & $5.0^{\mathrm{a}}$ & $247.4^{\mathrm{a}}$ & $28.1^{\mathrm{a}}$ & $220.5^{\mathrm{a}}$ \\
\hline $\mathbf{N}_{1} \mathbf{F}_{3}$ & $25.9^{\mathrm{a}}$ & $34.5^{\mathrm{ab}}$ & $76.4^{\mathrm{a}}$ & $82.1^{\mathrm{a}}$ & $5.1^{\mathrm{a}}$ & $249.0^{\mathrm{a}}$ & $28.2^{\mathrm{a}}$ & $231.7^{\mathrm{a}}$ \\
\hline $\mathbf{N}_{1} \mathbf{F}_{4}$ & $25.0^{\mathrm{a}}$ & $34.1^{\mathrm{ab}}$ & $57.2^{\mathrm{c}}$ & $57.4^{b}$ & $5.0^{\mathrm{a}}$ & $251.7^{\mathrm{a}}$ & $28.4^{\mathrm{a}}$ & $230.5^{\mathrm{a}}$ \\
\hline $\mathbf{N}_{2} \mathbf{F}_{1}$ & $25.1^{\mathrm{a}}$ & $36.0^{\mathrm{a}}$ & $72.6^{\mathrm{a}}$ & $84.5^{\mathrm{a}}$ & $5.4^{\mathrm{a}}$ & $259.1^{\mathrm{a}}$ & $29.0^{\mathrm{a}}$ & $235.6^{\mathrm{a}}$ \\
\hline $\mathbf{N}_{2} \mathbf{F}_{2}$ & $25.1^{\mathrm{a}}$ & $33.8^{\mathrm{ab}}$ & $70.5^{\mathrm{ab}}$ & $89.4^{\mathrm{a}}$ & $5.2^{\mathrm{a}}$ & $258.0^{\mathrm{a}}$ & $28.9^{\mathrm{a}}$ & $232.2^{\mathrm{a}}$ \\
\hline $\mathbf{N}_{2} \mathbf{F}_{3}$ & $25.0^{\mathrm{a}}$ & $34.7^{\mathrm{ab}}$ & $73.0^{\mathrm{a}}$ & $84.2^{\mathrm{a}}$ & $5.3^{\mathrm{a}}$ & $257.3^{\mathrm{a}}$ & $28.9^{\mathrm{a}}$ & $226.8^{\mathrm{a}}$ \\
\hline $\mathbf{N}_{2} \mathbf{F}_{4}$ & $24.8^{\mathrm{a}}$ & $33.3^{\mathrm{ab}}$ & $54.3^{c}$ & $58.4^{\mathrm{b}}$ & $5.4^{\mathrm{a}}$ & $261.2^{\mathrm{a}}$ & $29.2^{\mathrm{a}}$ & $227.9^{a}$ \\
\hline $\mathbf{N}_{3} \mathbf{F}_{1}$ & $25.1^{\mathrm{a}}$ & $30.0^{\mathrm{ab}}$ & $69.1^{\mathrm{ab}}$ & $84.3^{\mathrm{a}}$ & $5.3^{\mathrm{a}}$ & $264.7^{\mathrm{a}}$ & $29.4^{\mathrm{a}}$ & $231.4^{\mathrm{a}}$ \\
\hline $\mathbf{N}_{3} \mathbf{F}_{2}$ & $25.1^{\mathrm{a}}$ & $30.9^{\mathrm{ab}}$ & $60.8^{\mathrm{bc}}$ & $81.1^{\mathrm{a}}$ & $5.5^{\mathrm{a}}$ & $265.7^{\mathrm{a}}$ & $29.5^{\mathrm{a}}$ & $228.4^{\mathrm{a}}$ \\
\hline $\mathbf{N}_{3} \mathbf{F}_{3}$ & $24.0^{\mathrm{a}}$ & $31.6^{\mathrm{ab}}$ & $70.0^{\mathrm{ab}}$ & $81.1^{\mathrm{a}}$ & $5.3^{\mathrm{a}}$ & $266.6^{\mathrm{a}}$ & $29.6^{\mathrm{a}}$ & $232.5^{\mathrm{a}}$ \\
\hline $\mathbf{N}_{3} \mathbf{F}_{4}$ & $23.4^{\mathrm{a}}$ & $28.4^{b}$ & $50.9^{c}$ & $54.3^{b}$ & $5.3^{\mathrm{a}}$ & $268.4^{\mathrm{a}}$ & $29.7^{\mathrm{a}}$ & $233.5^{\mathrm{a}}$ \\
\hline S.Em. \pm & 0.98 & 2.82 & 3.37 & 5.03 & 0.2 & 8.35 & 0.64 & 8.18 \\
\hline \multicolumn{9}{|c|}{ Single control (SC) } \\
\hline SC & 30.97 & 31.79 & 75.81 & 83.15 & 5.2 & 247.6 & 28.1 & 224.2 \\
\hline S.Em. \pm & 1.20 & 3.37 & 3.50 & 5.01 & 0.2 & 7.67 & 0.59 & 5.33 \\
\hline LSD (0.05) & 3.50 & 9.85 & 10.20 & 14.61 & NS & NS & NS & NS \\
\hline \multicolumn{9}{|c|}{ 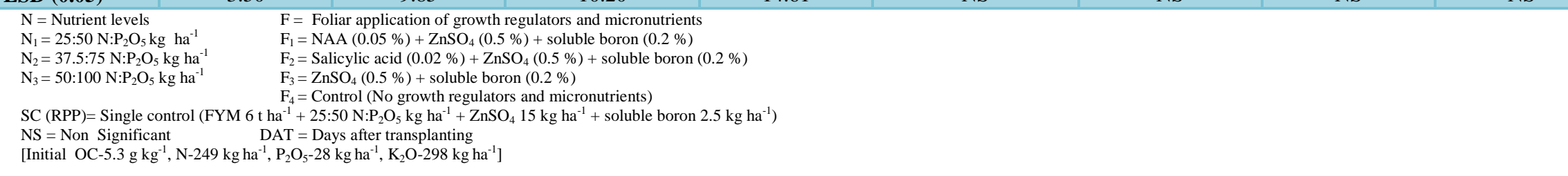 } \\
\hline
\end{tabular}


Application of 50:100 N: $\mathrm{P}_{2} \mathrm{O}_{5} \mathrm{~kg}$ per ha along with foliar spray of NAA $(0.05 \%)+\mathrm{ZnSO}_{4}$ $(0.5 \%)+$ soluble boron $(0.2 \%)$, foliar spray of $\mathrm{ZnSO}_{4}(0.5 \%)+$ soluble boron $(0.2 \%)$ and no spray and application of 37.5:75 $\mathrm{N}: \mathrm{P}_{2} \mathrm{O}_{5}$ $\mathrm{kg}$ per ha along with foliar spray of salicylic acid $(0.02 \%)+\mathrm{ZnSO}_{4}(0.5 \%)+$ soluble boron $(0.2 \%)$, foliar spray of $\mathrm{ZnSO}_{4}(0.5 \%)$ + soluble boron $(0.2 \%)$ recorded on par results with each other. At harvest, application of 50:100 N: $\mathrm{P}_{2} \mathrm{O}_{5} \mathrm{~kg}$ per ha along with foliar spray of micronutrients and growth regulators and foliar spray of micronutrients alone recorded significantly higher nitrogen content when compared to single control and application of $37.5: 75 \mathrm{~N}: \mathrm{P}_{2} \mathrm{O}_{5} \mathrm{~kg}$ per ha along with foliar spray of micronutrients and growth regulators.

Significantly higher phosphorus and potassium uptake at 90 DAT and at harvest was recorded with application of 50:100 $\mathrm{N}: \mathrm{P}_{2} \mathrm{O}_{5} \mathrm{~kg}$ per ha along with foliar spray of micronutrients and growth regulators and foliar spray of micronutrients alone recorded significantly higher phosphorus and potassium uptake when compared to single control and application of 37.5:75 N: $\mathrm{P}_{2} \mathrm{O}_{5} \mathrm{~kg}$ per hectare along with foliar spray of micronutrients and growth regulators (Table 2).

At harvest, significantly higher zinc uptake (Table 3) was recorded with application of 25:50 N: $\mathrm{P}_{2} \mathrm{O}_{5} \mathrm{~kg}$ per ha along with foliar spray of micronutrients and growth regulators, application of 25:50 N: $\mathrm{P}_{2} \mathrm{O}_{5} \mathrm{~kg}$ per ha along with foliar spray of micronutrients alone. Application of 37.5:75 N: $\mathrm{P}_{2} \mathrm{O}_{5} \mathrm{~kg}$ per ha along with foliar spray NAA $(0.05 \%)+$ $\mathrm{ZnSO}_{4}(0.5 \%)+$ soluble boron $(0.2 \%)$, application of 37.5:75 N:P $\mathrm{P}_{2} \mathrm{O}_{5} \mathrm{~kg}$ per ha along with foliar spray salicylic acid $(0.02 \%)+$ $\mathrm{ZnSO}_{4}(0.5 \%)+$ soluble boron $(0.2 \%)$, application of 37.5:75 N: $\mathrm{P}_{2} \mathrm{O}_{5} \mathrm{~kg}$ per hectare along with foliar spray $\mathrm{ZnSO}_{4}(0.5 \%)+$ soluble boron (0.2\%), application of 50:100 $\mathrm{N}: \mathrm{P}_{2} \mathrm{O}_{5} \mathrm{~kg}$ per hectare along with foliar spray NAA $(0.05 \%)+\mathrm{ZnSO}_{4}(0.5 \%)+$ soluble boron $(0.2 \%)$, application of $50: 100 \mathrm{~N}: \mathrm{P}_{2} \mathrm{O}_{5}$ $\mathrm{kg}$ per hectare along with foliar spray $\mathrm{ZnSO}_{4}$ $(0.5 \%)+$ soluble boron $(0.2 \%)$. Single control treatment showed higher zinc uptake (30.97 $\mathrm{g} \mathrm{ha}^{-1}$ ) at 90 DAT when compared to other treatment combinations.

At harvest, higher boron uptake was recorded with application of $37.5: 75 \mathrm{~N}: \mathrm{P}_{2} \mathrm{O}_{5} \mathrm{~kg}$ per ha and 50:100 N: $\mathrm{P}_{2} \mathrm{O}_{5} \mathrm{~kg}$ per ha along with foliar spray of micronutrients and growth regulators, foliar spray of micronutrients alone and single control. Significantly lower boron uptake was recorded with no spray.

\section{Acknowledgement}

I deem it a proud privilege to express my deepest sense of gratitude and thanks to my considerate advisor, Dr. H. B. Babalad, Professor and head, Dept. of Agronomy, college of Vijayapura, University of Agricultural Sciences, Dharwad and chairman of my Advisory Committee for his inspiring and noble guidance. I express my esteemed heartfelt thanks to the members of my Advisory Committee, Dr. H. T. Chandranath, Professor, Department of Agronomy, University of Agricultural Sciences, Dharwad and Dr. P. L. Patil, Professor, Department of Soil Science and Agricultural Chemistry, University of Agricultural Sciences, Dharwad for their constant encouragement, valuable suggestions, sensible criticism and constructive guidance during the course of this investigation.

\section{References}

Amin, S., Zaharah, A. R. and Che, F. I., 2014, Interaction effects of phosphorus and zinc on their uptake and phosphorus absorption and translocation in sweet corn (Zea mays var. Saccharata) grown in a 
tropical soil. Asian J. Plant Sci., 13(3): 129-135.

Chandrasekar, C. N. and Bangarusamy, U., 2003, Maximizing the yield of mungbean by foliar application of growth regulating chemicals and nutrients. Madras Agric. J., 90(1-3): 142-145.

Devrajan, R., Sheriff, M. M., Ramanathan, G. and Selvankumari, G., 1980, Effect of phosphorus and zinc fertilization on yield, content and its uptake by pulse crops. Indian J. Res., 14(1): 47-52.

Habib, M., 2012, Effect of supplementary nutrition with $\mathrm{Fe}, \mathrm{Zn}$ chelates and urea on wheat quality and quantity. African $J$. Biotechnol., 11(11): 2661-2665.

Jamadar, M. I., Sajjan, A. S. and Kumar, S., 2014, Economic analysis of seed production in transplanted pigeonpea [Cajanus cajan (L.) Millsp.]. Int. J. Com. Bus. Manage., 7(1): 63-66.

Rajabi, L., Sajedi, N. A. and Roshandel, M., 2013, Response of yield and yield component of dry land chickpea to salicylic acid and super absorbent polimer. J. Crop Prodn. Res., 4(4): 343353.

Raju, A., Rathod, P. S., Dharmaraj and Chavan, M., 1991, Influence of different nutrient levels application on yield and economics of chickpea. Karnataka J. Agric. Sci., 25(3): 482-485.

Rameshwar, P., 2003, Impact of foliar application of indole acetic acid (IAA), boron and zinc on physiology and sink capacity of pigeonpea [Cajanus cajan (L.) Millsp.]. M.Sc. (Agri.) Thesis, Indira Gandhi Agric. Univ., Raipur.

Siddaraju, R., 2008, Influence of varieties, planting densities and fertilizer levels on seed yield and quality of cluster bean (Cyamopsis tetragonoloba (L.) Taub.). Ph. D. Thesis, Univ. Agric. Sci., Bangalore, Karnataka, India.

Singh, R. S., Srivastava, G. P. and Sanjay, K., 2006, Fertilizer management in pigeonpea based intercropping systems. II. Nutrient removal and net change in soil fertility. $J$. Crop Res. (BAU), 18(1): 39-43.

Singh, S. K., Kumari, N., Karmakar, S., Puran, A. N. and Pankaj, S. C., 2016, Productivity, economics and nutrient uptake of hybrid pigeonpea as influenced by different fertility and lime levels under rainfed conditions. Environ. Ecol., 34(2) 726-729.

Srivastava, G. P. and Srivastava, V. C., 1993, Response of rainfed pigeonpea (Cajanus cajan) to phosphorus and sulphur in acid red- loam soil (Paleustalf). Indian $J$. Agric. Sci., 63(1): 43-44.

Sudhir, K. S., 2010, Effect of nutrient levels and lime on productivity of hybrid pigeon pea (Cajanus cajan L.). M.Sc. (Agri.) Thesis, Birsa Agric. Univ., Ranchi, Jharkhand.

Sujatha H. T. and Babalad H. B., 2018, System Productivity and Economics of Transplanted and Direct Sown Pigeonpea at Different Cropping Geometry and Intercropping Systems Int. J. Pure App. Biosci. 6 (1): 694-700.

Vitthal, D. S., 2001, Physiological studies on chemical regulation of translocatoin of assimilates in groundnut (Arachis hypogaea L.). Ph. D. Thesis. Mahatma Phule Krishi Vidy Apeeth, Rahuri, Ahmednagar, Maharashtra, India.

\section{How to cite this article:}

Lavanya, C., H.B. Babalad and Patil, P.L. 2020. Impact of Nutrient Levels and Growth Regulators on Yield, Plant Nutrient Content, Plant Nutrient Uptake and Soil Nutrient Content of transplanted pigeonpea in Northern Transition Zone of Karnataka. Int.J.Curr.Microbiol.App.Sci. 9(08): 449-459. doi: https://doi.org/10.20546/ijcmas.2020.908.053 